\title{
EVALUASI DESAIN JALAN KOTA BARU LAMPUNG MENURUT KAIDAH- KAIDAH PENGEMBANGAN WILAYAH BERWAWASAN LINGKUNGAN
}

\section{DESIGN EVALUATION OF KOTA BARU LAMPUNG ROAD ACCORDING TO THE ENVIRONMENTAL PRINCIPLES OF REGIONAL DEVELOPMENT}

\author{
Zulkarnain $^{1)}$ Ronny Hasudungan Purba ${ }^{2)}$ Tjetjeng Sofjan Surjana ${ }^{3)}$ \\ Universitas Bandar Lampung, Program Pascasarjana \\ Email : zulkarnain.serai@gmail.com
}

Dikirim 25 Juni 2020; Direvisi 10 Juli 2020; Disetujui 27 Juli 2020

\begin{abstract}
Abstrak: Pengembangan suatu kawasan haruslah memikirkan keberlanjutan suatu kawasan tersebut baik itu dari faktor ekonomi, sosial, dan lingkungan. Kota Baru Lampung sebagai kawasan pengembangan pusat pemerintahan Provinsi Lampung sangatlah perlu dikembangkan sebagai kawasan yang berwawasan lingkungan. Jalur hijau jalan merupakan bagian lansekap di area ruang milik jalan (rumija) yang mempunyai fungsi keselamatam dan kenyamanan pengguna jalan, penunjang kegiatan edukasi, rekreasi dan konservasi, estetika dan identitas kawasan serta menjadi pembentuk karakter suatu kota. Fungsi tanaman pada lanskap jalan adalah untuk mengurangi paparan cahaya matahari langsung dan lampu kendaraan, sebagai pengarah, pembatas fisik, mengendalikan pergerakan, mengontrol iklim mikro, dan habitat satwa. Penelitian ini bertujuan mengevaluasi area ruang milik jalan (rumija) sebagai jalur hijau jalan dari fungsi estetika, kenyamanan dan keselamatan, mendesain ruang milik jalan (rumija) yang sesuai dengan peraturan yang berlaku serta memperhatikan dari pada prinsip-prinsip pembangunan jalan berkelanjutan, Berdasarkan hasil evaluasi, diperlukan beberapa hal yang merupakan interpretasi terhadap informasi (data) hasil evaluasi, sebagai berikut: 1.) Pengembangan suatu kawasan baru haruslah menerapkan prinsip - prinsip pembangunan jalan berkelanjutan agar dapat dampak-dapak negative dari pembangunan suatu kawasan dapat diminimalisir. 2.) Kondisi ruang milik jalan (rumija) dan perencanaan masterplan Kota Baru perlu dievaluasi untuk memenuhi standar jalan yang berwawasan lingkungan yang disyaratkan minimal ruang terbuka hijau (RTH) Publik 20\%, dengan menerapkan kaidah-kaidah pembangunan jalan yang berwawasan lingkungan. 3.) Konsep desain ruang milik jalan yang berwawasan lingkungan selayaknya di implementasikan dan dikembangkan dalam setiap pengembangan suatu wilayah.
\end{abstract}

Kata kunci: Evaluasi Desain, Ruang Milik Jalan, Berkelanjutan, Kota Baru Lampung.

\begin{abstract}
Evaluasi Desain, Ruang Milik Jalan, Berkelanjutan, Kota Baru Lampung. Center for the central government of Lampung Province really needs to be developed as an environmentally friendly region. Green lane road is part of the landscape in the right of way area (r.o.w) which has the function of safety and comfort to road users, supporting educational activities, recreation and conservation, aesthetics and identity of the area as well as forming the character of a city. The function of plants on the road landscape is to reduce exposure to direct sunlight and vehicle lights, as a guide, physical barriers, controlling movement, controlling microclimate, and animal habitat. This study aims to evaluate the right of way area (r.o.w) as a green road from aesthetic, comfort and safety functions, designing right of way (r.o.w) in accordance with regulations with attention to the principles of sustainable road development. Based on evaluation results, there are several things which stems from interpretations of the information (data) resulted from the evaluation, which are: 1.) The development of a new area must adhere to the principles of sustainable road development so that the negative impacts from the development of an area can be minimized. 2.) The condition of right of way (r.o.w) and the planning of the Kota Baru master plan need to be evaluated to meet environmental standards that are required to have a minimum of $20 \%$ open green space (RTH), by applying the principles of environmentally sound road development. 3.) The design concept of right of way that has an environmental insight, should be implemented and promoted in every development of an area.
\end{abstract}

Keywords: Design Evaluation, Street Space, Sustainable, Kota Baru Lampung. 


\section{PENDAHULUAN}

Dasar dari konsep pembangunan berkelanjutan berawal dari penggunaan sumber daya alam secara besar-besaran untuk menaikkan kemakmuran rakyat (ekonomi) namun tanpa memperhatikan penggunaan sumber daya alam dan teknologi canggih yang kemudian menyebabkan kerusakan lingkungan. Pembangunan berkelanjutan merupakan upaya untuk memenuhi kebutuhan dasar semua dan berkembang menjadi kesempatan untuk memuaskan aspirasi manusia untuk kehidupan yang lebih baik. Dapat digambarkan bahwa pilar yang mendukung sifat berkelanjutan adalah aspek sosial (dikenal sebagai kebutuhan standar manusia), aspek lingkungan (dikenal sebagai ekologi atau bumi), dan aspek ekonomi (dikenal sebagai uang atau keuntungan).

Kawasan perkotaan di Indonesia cenderung mengalami permasalahan yang tipikal, yaitu tingginya tingkat pertumbuhan penduduk. Hal ini terutama akibat arus urbanisasi sehingga menyebabkan pengelolaan ruang kota makin berat. Jumlah penduduk perkotaan yang tinggi dan terus meningkat dari waktu ke waktu tersebut akan memberikan implikasi pada tingginya tekanan terhadap pemanfaatan ruang kota, sehingga penataan ruang kawasan perkotaan perlu mendapat perhatian yang khusus terutama yang terkait dengan penyediaan kawasan hunian, fasilitas umum dan sosial serta ruang ruang terbuka publik (open spaces) di perkotaan. Salah satu penyebab terjadinya penurunan kualitas dan kuantitas lingkungan di perkotaan adalah karena pemanfaatan ruang terbuka hijau tidak optimal sebagai kawasan resap air dan kurang kesadaran masyarakat untuk membuang sampah yang kurang dan dapat menyebabkan terjadinya banjir.

Kecenderungan yang terjadi pada kawasan perkotaan saat ini adalah mengembalikan pemukimannya menuju kearah keseimbangan antara ruang terbuka hijau dengan ruang terbangun atau ruang non-hijau sehingga dapat tercapai kawasan perkotaan dengan kondisi lingkungan yang sehat dan nyaman. Keberadaan ruang terbuka hijau penting dalam mengendalikan dan memelihara integritas lingkungan. Kelestaian ruang terbuka hijau suatu wilayah perkotaan harus disertai dengan ketersediaan dan seleksi tanaman yang sesuai dengan arah rencana dan rancangannya. Berbagai fungsi yang terkait dengan keberadaannya (fungsi ekologi, sosial, ekonomi, dan arsitektur) dan nilai estetika yang dimilikinya (objek dan lingkungan) tidak hanya di dapat dalam meningkatkan kualitas lingkungan dan untuk kelangsungan kehidupan masyarakat perkotaan tetapi juga dapat menjadi nilai kebanggaan dan identitas kota tersebut.

Undang-Undang Nomor 26 Tahun 2007 tentang Penataan Ruang dengan tegas mempersyaratkan penyediaan Ruang Terbuka Hijau (RTH) di kawasan perkotaan sebesar minimal 30\% dari luas wilayah, yang terdiri dari $20 \%$ RTH publik dan $10 \%$ RTH privat, agar tercapai ruang yang aman, nyaman, produktif dan berkelanjutan. Secara umum ruang terbuka publik (open spaces) di perkotaan terdiri dari ruang terbuka hijau dan ruang terbuka non-hijau. Ruang Terbuka Hijau (RTH) perkotaan adalah bagian dari ruang-ruang terbuka (open spaces) suatu wilayah perkotaan 
yang diisi oleh tumbuhan, tanaman dan vegetasi baik endemik maupun introduksi guna mendukung manfaat ekologis, sosialbudaya dan arsitektural yang dapat memberikan manfaat ekonomi (kesejahteraan) bagi masyarakatnya. Sementara itu ruang terbuka non-hijau dapat berupa ruang terbuka yang diperkeras (paved) maupun ruang terbuka biru (RTB) yang berupa permukaan sungai, danau, maupun areal-areal yang diperuntukkan sebagai kolam-kolam retensi.

Berdasarkan Peraturan Menteri Pekerjaan Umum Nomor : 05/PRT/M/2008 tentang pedoman penyediaan dan pemanfaatan RTH di kawasan Perkotaan ini juga terdapat pula peraturan tentang: 1.) RTH Jalur Hijau Jalan mencakup : pulau jalan dan median jalan, taman pulau jalan maupun median jalan selain berfungsi sebagai RTH, juga dapat di manfaatkan untuk fungsi lain seperti sebagai pembentuk arsitektur kota. Jalur tanaman tepi jalan atau pulau jalan selain sebagai wilayah konservasi air, juga dapat dimanfaatkan untuk keindahan/estetika kota. Median jalan dapat dimanfaatkan sebagai penahan debu dan keindahan kota. 2.) RTH Jalur Pejalan Kaki mencakup : RTH jalur pejalan kaki dapat dimanfaatkan sebagai Fasilitas untuk memungkinkan terjadinya interaksi social baik pasif maupun aktif serta memberi kesempatan untuk duduk dan melihat pejalan kaki lainnya dan Sebagai peyeimbang temperature, kelembaban, tekstur bawah kaki, vegetasi, emisi kendaraan, vegetasi yang mengeluarkan bau, sampah yang baud an terbengkalai, faktor audial (suara) dan faktor visual.

Menurut Peraturan Menteri Dalam Negeri tentang Penataan Ruang Terbuka
Hijau Kawasan Perkotaan (RTHKP) Nomor 1 Tahun 2007 Pasal 6 Jenis Ruang Terbuka Hijau Kawasan Perkotaan terbagi menjadi 23 jenis, yang juga mencakup juga jalur pegaman jalan, median jalan, pendestrian , serta kawasan dan jalur hijau masih merupakan RTHKP di Dalam Permendagri Nomor 1 Tahun 2007.

Sesuai dengan Rencana Tata Ruang Wilayah (RTRW) Provinsi Lampung Tahun 2009-2029 memiliki tujuan dalam penataan ruang wilayah Provinsi Lampung yaitu : "Terwujudnya Keterpaduan Penataan Ruang Provinsi Lampung untuk Mendukung Pembangunan yang Berkelanjutan dan Berdaya Saing”.

Terkait dengan pelaksanaan UndangUndang Penataan Ruang dalam penyediaan ruang terbuka hijau, maka upaya penyediaan ruang terbuka hijau di Provinsi Lampung seharusnya terencana dengan baik agar ketersediaan ruang terbuka hijau menjadi salah satu prioritas dalam pembangunan infrastruktur.

Pertumbuhan dan perkembangan kota sangat dipengaruhi oleh pertumbuhan penduduk. Semakin meningkat jumlah penduduk, maka semakin meningkat pula kebutuhan ruang dan lahan. Kebutuhan ruang dan lahan yang meningkat terutama untuk kegiatan permukiman, kegiatan perekonomian, kegiatan sosial dan lainnya bahkan juga ikut meningkatkan kebutuhan ruang dan lahan untuk infrastruktur, sarana dan prasarana pendukungnya.

Mengidentifikasi prinsip-prinsip pembangunan jalan berkelanjutan. Identifikasi prinsip dilakukan pada bidang transportasi jalan dan pembangunan jalan. Prinsip-prinsip tersebut dikelompokkan pada aspek-aspek pembangunan 
berkelanjutan dan dilakukan identifikasi contoh-contoh yang terkait. Dari rangkaian prinsip-prinsip tersebut diidentifikasi prinsip-prinsip yang harus ada dan yang dapat diterapkan pada suatu pembangunan jalan.

\section{RUMUSAN MASALAH}

Pada ruang milik jalan (rumija) pada masterplan dan kondisi pelaksanaan pembangunan Kota Baru Lampung pada saat ini apakah telah memenuhi peraturan dan prinsip-prinsip pembangunan jalan berkelanjutan yang berlaku dan sering kali tidak diperhatikan dalam suatu pengembangan wilayah suatu tempat untuk memanimalisir kemungkinan dampak negatif yang timbul akibat pengembangan kawasan tersebut dari sisi lingkungan, sosial, keamanan, dan lainnya, maka Prinsip-prinsip Pembangunan jalan berkelanjutan pada ruang milik jalan (rumija) dalam perencanaan jalan haruslah diperhatikan dengan tidak mengidahkan kapasitas jalan dalam perkembangan tranportasi suatu wilayah.

\section{TUJUAN}

Mengacu pada kondisi aktual di lapangan maka tujuan dari penelitian ini adalah:

1. Mengetahui

kaidah-kaidah pembangunan yang berwawasan lingkungan.

2. Mengevaluasi jalan di Kota Baru Lampung dalam konsep pembangunan jalan yang berkelanjutan untuk membentuk pembangunan kota berkelanjutan.

3. Menganalisis kapasitas jalan di Kota Baru Lampung dengan mengacu pada rata - rata kondisi jalan di sekitar wilayah Kota Baru.

4. Menberikan saran desain permodelan jalan pada suatu kawasan Kota Baru.

\section{TINJAUAN PUSTAKA}

\section{Tantangan Pembangunan}

\section{Transportasi}

Transportasi memberikan pengaruh terhadap lingkungan meliputi konstruksi infrastruktur transportasi, perjalanan, perakitan perlengkapan transportasi, pemeliharaan infrastruktur, dan fasilitas lain pendukung kendaraan.

- Rata-rata pengaruh transportasi, seperti polusi udara, gas rumah kaca, dan emisi, suatu perjalanan pernah dihitung. Termasuk pengaruh lainnya, seperti perubahan habitat, kualitas air, pengaruh pabrik yang memproduksi kendaraan, pemeliharaan fasilitas, belum pernah pula ditelusuri.

- Definisi green roads adalah kegiatan penyelenggaraan jalan yang menerapkan prinsip lingkungan dimulai dari tahap pembiayaan, perencanaan, desain, konstruksi, dan pemeliharaan jalan. serta penanganan dampak perubahan iklim. - $\quad$ Prinsip lingkungan adalah prinsip yang mengedepankan dan memperhatikan unsur pelestarian lingkungan seperti pemanfaatan secara efektif dan efisien sumber daya air dan energi, pengurangan limbah dan polusi, dan pensinergisan lingkungan alami dan buatan

- Pembangunan berkelanjutan merupakan upaya untuk memenuhi kebutuhan dasar semua dan berkembang menjadi kesempatan untuk memuaskan aspirasi manusia untuk kehidupan yang lebih baik. Hal-hal yang mendukung sifat 
berkelanjutan dapat digambarkan menjadi tiga pilar, yaitu aspek sosial (dikenal sebagai kebutuhan standar manusia), aspek lingkungan (dikenal sebagai ekologi atau bumi), dan aspek ekonomi (dikenal sebagai uang atau keuntungan)

Wheeler dan Beatley (2004) dalam Lawalata (2013), : Tiga pilar yang mendukung sifat berkelanjutan, yang saling berinteraksi satu sama lain (Lingkungan, Sosial, Ekonomi)

Kebutuhan manusia disebut berkelanjutan jika kebutuhan standar bisa didapatkan dalam waktu yang panjang.

Kebutuhan standar yang dimaksud meliputi udara, air, dan sumber daya alam lainnya.

\section{Definisi Pembangunan berkelanjutan}

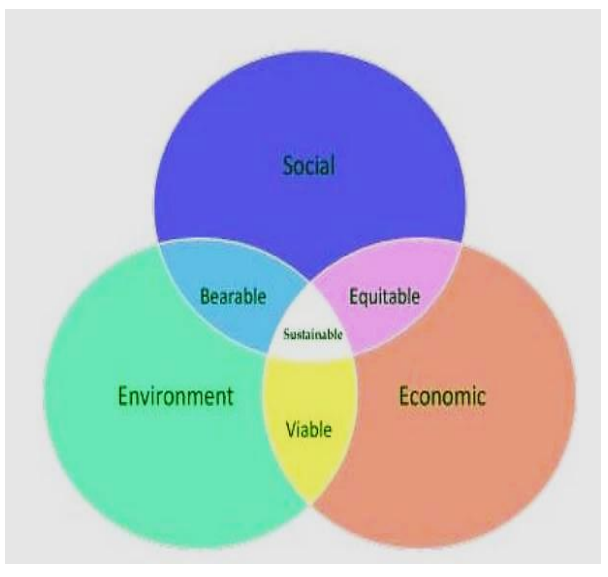

Gambar 1 Diagram Venn Pembangunan Berkelanjutan

Lingkungan dapat memberi kebutuhan dasar manusia sebagai makhluk sosial (bearable). Kebutuhan dasar manusia terhadap ekonomi disebut berkelanjutan jika memiliki kesamaan kesempatan (equitable) untuk mendapat pemenuhan kebutuhan. Sedangkan kebutuhan kegiatan ekonomi yang berkelanjutan tidak lepas dari ketersediaan lingkungan, seperti udara, air, tanaman, hewan dalam waktu yang lama (viabel) untuk ekonomi, sosial dan lingkungan.

\section{Definisi Transportasi berkelanjutan}

- Menurut Organisation for Economic Cooperation and Development (OECD) adalah transportasi yang tidak membahayakan kesehatan publik atau ekosistem dan memenuhi kebutuhan mobilitas.

- Transportasi berkelanjutan harus konsisten dengan penggunaan sumber daya alam yang terbarukan di bawah kecepatan perkembangannya dan penggunaan non-sumber daya alam yang bukan terbarukan di bawah rata-rata perkembangan yang dapat mengganti.

Sistem transportasi yang berkelanjutan merupakan pemenuhan kebutuhan dasar akses individu dan manusia agar selamat dan konsisten mempertimbangkan kesehatan manusia dan ekosistem, dan kesetaraan antar generasi.

Sistem transportasi tersebut harus :

Terjangkau, beroperasi dengan efisien, memberikan pilihan-pilihan moda transportasi, dan mendukung perekonomian.

- Pembatasan emisi dan buangan antara kemampuan planet untuk menyerapnya,

- Meminimumkan konsumsi sumber daya alam tidak terbarukan,

- Membatasi penggunaan sumber daya alam tidak terbarukan pada tingkat berkelanjutan,

- Penggunaan kembali dan penggunaan kembali komponen, dan 
- Meminimumkan lahan yang menghasilkan kebisingan

\section{Definisi Pembangunan Jalan Berkelanjutan}

Mulmi (2009) dalam Lawalata (2013) menyatakan bahwa:

- Pendekatan konstruksi jalan berkelanjutan merupakan pendekatan yang terbaik, khususnya di situasi medan pegunungan, seperti yang terdapat di Nepal-India.

- Penerapan konsep yang berfokus pada aspek lingkungan, sosial, dan ekonomi tersebut memberikan penghematan biaya sekitar 65\% terhadap total biaya konstruksi.

- $\quad$ Konsep jalan berkelanjutan, yang disebut pula sebagai jalan hijau, menggunakan material lokal dan menggunakan partisipasi masyarakat lokal di setiap tahap proyek.

\section{Definisi : Green roads Summit (2011)}

Jalan Hijau adalah :

Proyek jalan yang dirancang dan dilaksanakan ke tingkat keberlanjutan yang lebih tinggi dari proyek jalan biasa

Tingkat keberlanjutan yang dikembangkan oleh Greenroads merupakan berbagai kegiatan dari perencanaan, perancangan jalan, konstruksi, dan pemeliharaan

New Road Construction Concepts Visison 2040, Green (environmentally friendly) Infrastructure bertujuan untuk meminimalkan dampak lingkungan pada masyarakat dan habitat alami merupakan konsep utama.

Infrastruktur hijau cocok dengan lingkungan dan memberikan kontribusi dengan cara desain dan komposisi untuk meminimalkan dampak lalu lintas (kebisingan, polusi udara dan getaran)

Undang-undang 38 tahun 2004 tentang Jalan, pasal 2 menyebutkan bahwa :

penyelenggaraan jalan berdasarkan pada asas kemanfaatan, keamanan dan keselamatan, keserasian, keselarasan, keseimbangan, keadilan, tranparansi, dan akuntabilitas, keberdayaan, dan keberhasilan, serta kebersamaan kemitraan.

Dengan demikian pendapat bahwa pembangunan berkelanjutan merupakan konsep multidimensi dapat diterima. Pada penerapan pembangunan berkelanjutan diperlukan masukan dari berbagai disiplin ilmu (Hall, 2006). Selain itu, dibutuhkan pula perencanaan yang komprehensif dan terintegrasi sehingga ada pengaruh pada ekonomi, sosial, dan lingkungan (Litman dan Greenberg).

Prinsip-prinsip pembangunan jalan berkelanjutan yang dikelompokan pada aspek-aspek sosial, ekonomi, dan lingkungan. Terlihat bahwa beberapa literatur menganut beberapa prinsip yang sama dan ada pula prinsip yang tidak dianutnya. Literatur yang paling lengkap adalah Greenroads, INVEST, dan I-Last karena ketiga literatur tersebut adalah pedoman yang khusus mengarahkan pembangunan jalan berkelanjutan sedangkan literature lainnya adalah praktek yang pernah dilakukan dalam mewujudkan jalan berkelanjutan.

Prinsip yang harus ada sebagai prinsip jalan berkelanjutan adalah efisiensi, mobilitas, aksesibilitas, selamat dan nyaman, partisipasi masyarakat, pembatasan emisi, sumber daya alam, 
habitat, dan ekosistem. Prinsip-prinsip tersebut dikelompokkan pada aspek-aspek ekonomi, sosial, dan lingkungan.

Prinsip efisiensi dengan perencanaan yang baik dapat memperpanjang umur layan jalan tersebut dan meminimumkan kegiatan pemeliharaan maupun rehabilitasi jalan. Hal ini dapat diwujudkan bila penyedia jasa perencana jalan telah memahami dan melaksanakan sistem manajemen mutu dan sistem manajemen lingkungan serta terdapat koordinasi yang baik antara perencana dan pelaksana di lapangan. Prinsip mobilitas dan aksesibilitas yang tinggi digambarkan dengan adanya kelancaran perjalanan dan resiko terjadi konflik lalulintas, sehingga terjadi penghematan biaya perjalanan.

Prinsip-prinsip yang harus ada terkait dengan aspek sosial adalah bahwa penyelenggaraan jalan memenuhi kebutuhan dan peningkatan kualitas perjalanan pengguna jalan, keselamatan (pengurangan jumlah kematian dan jumlah kecelakaan), serta kebutuhan pengguna jalan, seperti mobilitas dan aksesibilitas, untuk melakukan kegiatan dengan nyaman dan dalam kondisi sehat. Partisipasi masyarakat merupakan prinsip yang harus ada karena yang merasakan manfaat adalah masyarakat. Dengan demikian perlu adanya partisipasi masyarakat dalam perencanaan jalan tersebut. Gambaran partisipasi masyarakat ini berupa pemberitahuan penempatan lokasi jembatan penyeberangan, dan lokasi pagar pemisah bagi pejalan kaki atau pesepeda. Teknis kegiatan ini dapat berupa pameran, diskusi terbuka, ataupun jajak pendapat.

Prinsip yang harus ada terkait dengan aspek lingkungan dalah bahwa penyelenggaraan jalan memperhatikan perlindungan dan mengurangi kerusakan lingkungan. Kegiatan yang terkait dengan prinsip ini misalnya adalah menggunakan teknologi dan melengkapi peralatan pencampuran dan penghamparan campuran beraspal panas untuk mengurangi emisi yang berasal dari peralatan yang digunakan. Kegiatan lainnya adalah pembatasan penggunaan material baru dan penggantian bahan bakar fosil dengan bahan bakar lainnya. Pembatasan ini dimaksudkan untuk melindungi sumber daya. Kegiatan lainnya adalah perlindungan kepunahan habitat dan ekosistem dengan menyediakan sarang tambahan dan dinding atau pagar untuk menghalangi hewan masuk ke area jalan.

V. Tepat Guna Lahan

- Proporsi Luas dan Kualitas Ruang Terbuka Hijau.

- Pembangunan/ Revitalisasi Kawasan

- Fasilitas Aksesibilitas Umum

- Fasilitas Terhadap Transportasi Umum.

- Fasilitas Bersepeda

- Pertamanan

- Kenyamanan Iklim Mikro

- Manajemen Pengelolaan Air Hujan

VI. Ruang Terbuka Hijau (RTH) Jalur Hijau Jalan Kawasan Kota

Untuk jalur hijau jalan, RTH dapat disediakan dengan penempatan tanaman antara $20 \%$ - 30\% dari ruang milik jalan (rumija) sesuai dengan klas jalan. Untuk menentukan pemilihan jenis tanaman, perlu memperhatikan 2 (dua) hal, yaitu fungsi tanaman dan persyaratan penempatannya. Disarankan agar dipilih jenis tanaman khas 
daerah setempat, yang disukai oleh burungburung, serta tingkat evapotranspirasi rendah. Serta disesuaikan dengan fungsi dari jenis - jenis tanaman yang dapat dilihat dari beberapa contoh pola tanam dibawah ini :

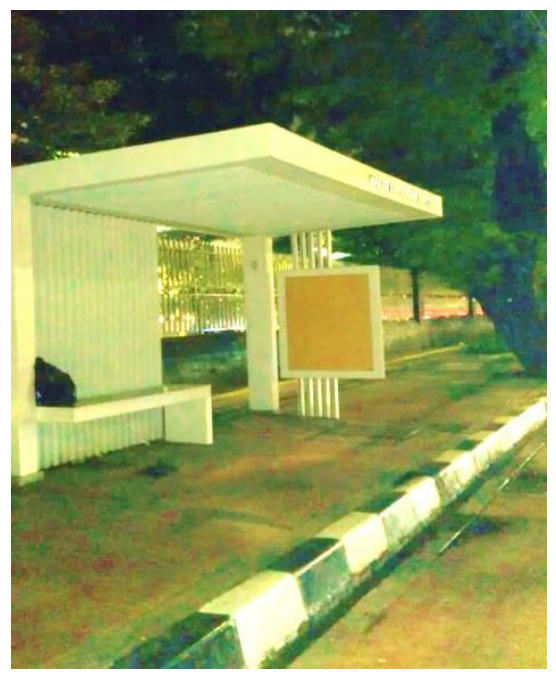

Gambar.2 Kondisi Halte di depan Masjid Istiqlal

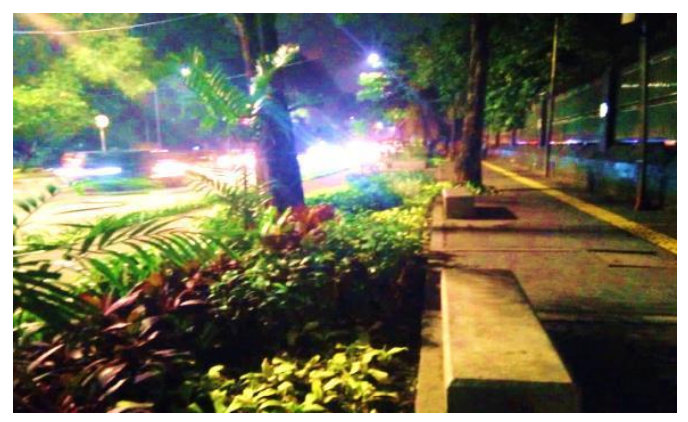

Gambar. 3 Kondisi Jalan Pendistrian di depan Masjid Istiqlal

\section{Landscape dan Soundscape}

a. Arsitektur landscape

Arsitektur

landscape atau seni taman adalah ilmu yang mempelajari tentang seni, perencanaan, perancangan, $\mathrm{m}$ anajemen, perawatan, dan perbaikan tanah dan perancangan konstruksi buatan manusia skala besar. Ruang lingkup dari profesi ini termasuk desain arsitektural, perencanaan lokasi, pengembangan estate, restorasi lingkungan, perencanaan kota, perencanaan taman dan rekreasi, perencan aan regional, perencanaan ruang, dan perawatan sejarah. Arsitek landscape dianggap merupakan sebuah profesi yang setara dengan dokter dan pengacara, karena mereka membutuhkan pengajaran khusus dan lisensi profesional, seperti yang dibutuhkan oleh pekerja profesional lainnya.

\section{b. Pengenalan Konsep Soundscape Soundscape adalah} komponen dari lingkungan akustik yang dapat dirasakan oleh manusia. Ada beragam sejarah penggunaan soundscape tergantung pada berbagai disiplin ilmu, mulai dari rancang kota (urban design) -dimana mungkin lebih diutamakan penerapannya pada konsep ini -- hingga ekologi fauna. Perbedaan penting adalah memisahkan soundscape dari lingkungan akustik yang lebih luas. Lingkungan akustik adalah kombinasi dari semua sumber akustik, alami dan buatan, dalam area tertentu yang dimodifikasi oleh lingkungan, sementara soundscape lebih kepada interaksi pihak yang terlibat di dalamnya.

Secara garis besar soundscape dalam arsitektur dan rancang kota diartikan sebagai penataan lansekap suatu bagian kota yang mengikutsertakan penataan suara (baik berasal dari bioponi, geoponi dan atau antroponi) dan indera manusia lainnya sehingga menghasilkan kesan pengetahuan yang mendalam tentang sesuatu hal.

Di beberapa kota dunia, exercise soundcape ini telah berhasil dilakukan. 
Penggugahan pengetahuan lewat alunan musik yang relevan berhasil dalam skala bagian wilayah kota, masyarakat terhanyut oleh suasana lingkungan atmosfer soundscape sehingga secara tidak tersadar telah digugahkan oleh suatu informasi pengetahuan tertentu. Perencanaan model ini berpeluang melibatkan beberapa keahlian dari berbagai disiplin ilmu, seperti para arsitek, arsitek lansekap, insinyur akustik, pemerhati pendidikan, sosiolog, antropolog dan keahlian lainnya. Suatu tantangan yang menarik mengingat membawa suatu tujuan besar guna merevitalisasi kejayaan lada (hitam) dan kopi robusta Lampung lewat pengedukasian tanaman lada dan penciptaan atmosfer Lampung yang kental.

\section{Dasar Teknis kapasitas Jalan}

Kapasitas Jalan menurut HCM (1994), adalah penilaian pada orang atau barang masih cukup layak dalam kemampuannya memindahkan sesuatu. Menurut Peraturan Menteri Perhubungan No: KM 14 Tahun 2006, "Kapasitas jalan adalah kemampuan ruas jalan untuk menampung volume lalu lintas ideal persatuan waktu, dinyatakan dalam kendaraan/jam." Kapasitas dapat diartikan juga sebagai arus lalu lintas maksimum yang dapat lewat pada waktu tertentu dengan kondisi yang ditetapkan. Faktor-faktor yang mempengaruhi kapasitas jalan diantaranya Kondisi geometri, Kondisi lalu lintas, Kondisi lingkungan,

\section{METODE PENELITIAN}

\section{Pendekatan Masalah}

Pendekatan masalah dilakukan dengan pendekatan peraturan-peraturan pemerintah dan pendekatana secara akademisi serta survey lapangan. Pendekatan secara normatif, yaitu pendekatan yang dilakukan dengan cara mengumpulkan dan mempelajari peraturan-peratuan pemerintah yang berlaku yang erat kaitannya dengan permasalah penelitian yang meliputi peraturan perundang-undangan, dokumendokumen resmi, dan sumber lain yang erat kaitannya dengan permasalahan yang diteliti. Pendekatan secara empiris, yaitu pendekatan yang dilakukan dengan cara melihat pada kenyataan langsung atau sesungguhnya, survey lapangan di lokasi penelitian dan mengumpulkan informasi yang berhubungan dengan permasalahan yang diteliti

\section{Sumber Data}

Sumber data yang dipergunakan dalam penelitian ini berupa data primer dan data sekunder. Data primer adalah data yang diperoleh dari studi lapangan, yaitu hasil survey lapangan dengan pengukuran lokasi, sedangkan data sekunder terdiri dari peraturan-peraturan pemerintah tentang tata ruang wilayah dan ruang terbuka hijau serta pendapat beberapa tenaga ahli di bidang pengembangan wilayah.

\section{Prosedur Pengumpulan dan Pengolahan Data}

a. Prosedur Pengumpulan Data

Prosedur pengumpulan data dalam penelitian ini dilakukan dengan cara sebagai berikut:

1. Studi kepustakaan (library research), yaitu melakukan serangkaian kegiatan seperti membaca, menelaah dan mengutip dari berbagai buku dan literature Serta melakukan pengkajian terhadap ketentuan peraturan perundang - undangan yang berkaitan permasalahan dalam penelitian 
2. Studi lapangan (field research) yang dilakukan melalui survey lapangan adalah usaha untuk mengumpulkan data dengan cara pengukuran lokasi, yaitu mendapatkan informan penelitian untuk memperoleh data yang dibutuhkan dalam penelitian.

b. Prosedur Pengolahan Data

Pengolahan data dalam penelitian ini meliputi tahapan pemeriksaan data, klasifikasi data, penyusunan data.

\section{Analisis Data}

Analisis data yang dipergunakan dalam penelitian ini adalah analisis kualitatif.gtrtrthgrt

\section{HASIL DAN PEMBAHASAN}

\section{Gambaran Umum Wilayah}

Kawasan Kota Baru Lampung berlokasi pada wilayah Kecamatan Jati Agung, Lampung Selatan.

Konsep pengembangan Kota Baru adalah kota mandiri, yaitu memadukan pusat pemerintahan dengan kawasan komersil. Menciptakan kota yang hijau (green city, eco city) dengan mempertahankan hutan sebagai bagian kota dengan komposisi 60:40. Selain itu, kawasan Kota Baru diterapkan batasan pembangunan perumahan skala besar dengan persil-persil lahan yang kecil serta memberikan porsi yang besar terhadap pergerakan non-motorized transportation.

Kondisi yang ada saat ini, perencanaan Masterplan Kota Baru Jati Agung sudah terlaksana di area Pusat Perkantoran Provinsi Lampung seluas $350 \mathrm{Ha}$, namun masih perlu dilanjutkan pembangunannya untuk menyempurnakan rancangan. Dalam menyusun masterplan kawasan, perkantoran, disusun mengikuti gari-garis kontur lahan, dengan menempatkan lokasi kantor gubernur sebagai center point/point of interest yang terletak satu garis lurus dengan monumen dan taman kota. Dalam penyusunan masterplan kawasan, dibagi dalam 3 zona, yaitu perkantoran, perumahan, dan rekreasi/olah raga.

Konsep kawasan Kota Baru dirancang mengikuti arahan sebagai suatu kawasan perkotaan yang aman, nyaman, dan asri (smart and green city). Dalam bidang transportasi, direncanakan menyediakan berbagai fasilitas pendukung untuk pergerakan orang tanpa kendaraan seperti pedestrian, jalur sepeda, dan penataan jarak antar kegiatan.

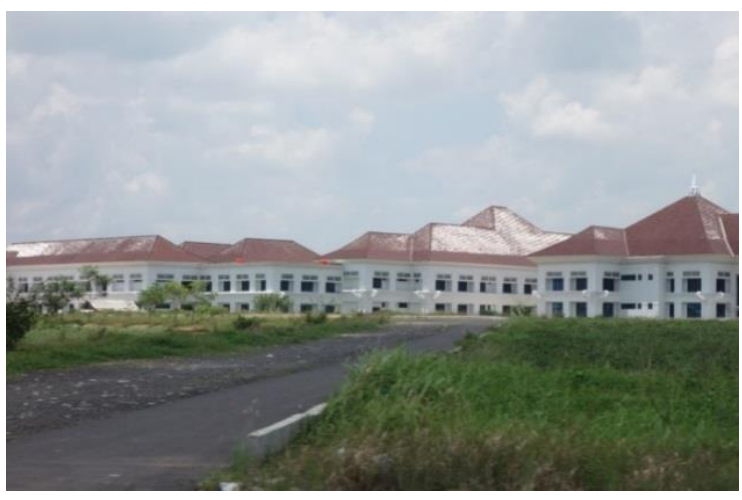

Gambar.4 Peta Masterplan Kota Baru Lampung

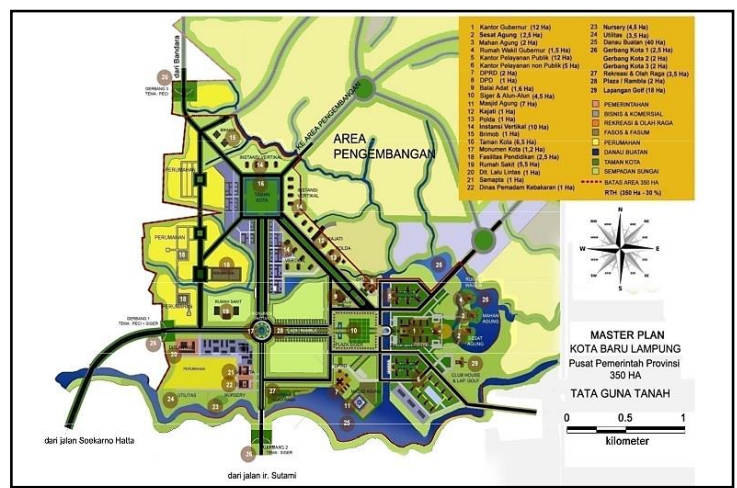

Gambar. 5 Kondisi Umum Jalan Utama di Kota Baru Lampung 


\section{Mengevaluasi jalan di Kota Baru} Lampung dalam konsep Ruang Terbuka Hijau.

a. Jalur Pedestrian

Dalam konsep arsitektur hijau, penggunaan energi dalam bentuk apa pun perlu diminimalkan. Aktivitas pergerakan manusia dari satu tempat ke tempat lain diusahakan tidak mengonsumsi energi apalagi untuk jarak perpindahan yang tidak terlampau jauh. Untuk itu diperlukan jalur pejalan kaki yang memadai. Rancangan jalur-jalur pedestrian yang tidak memadai akan membuat warga enggan berjalan kaki, sehingga terdorong menggunakan kendaraan bermotor meskipun untuk menempuh jarak pendek sekalipun.

\section{b. Tranportasi Kawasan}

Jalur transportasi, baik jalan kendaraan, jalur sepeda, jalur pedestrian, perlu diteduhi dengan pohon-pohon pelindung sehingga pengguna jalan ataupun jalur pedestrian terlindung dari sengatan matahari. Di sisi lain pemanasan terhadap perkerasan dan jalur kendaraan akibat radiasi matahari dapat diminimalkan, sehingga efek "heat Island" atau pemanasan kawasan juga dapat diminimalkan.

\section{Menganalisis kapasitas jalan di kota} baru Lampung dengan mengacu pada rata - rata kondisi jalan di sekitar wilayah

\section{Kota Baru.}

Penilaian kinerja ruas jalan dilakukan secara analitis dengan metode Manual Kapasitas Jalan Indonesia (MKJI, 1997). Kapasitas ruas jalan yang memiliki median, kapasitas dihitung untuk masing-masing arah. Sedangkan ruas jalan yang tidak bermedian, kapasitas dihitung untuk kedua arah. Untuk parameter penilaian kinerja biasanya digunakan nilai derajat kejenuhan
(DS) atau juga dikenal dengan istilah V/Cratio.

Kapasitas ruas jalan dihitung dengan mengalikan kapasitas dasar jalan dengan faktor-faktor penyesuaian yaitu faktor penyesuaian kapasitas dasar $\left(\mathrm{C}_{\mathrm{O}}\right)$, faktor penyesuaian kapasitas untuk lebar jalur lalu lintas $\left(\mathrm{F}_{\mathrm{CW}}\right)$, faktor penyesuaian kapasitas untuk pemisahan arah $\left(\mathrm{F}_{\mathrm{CSP}}\right)$, faktor penyesuaian kapasitas untuk hambatan samping $\left(\mathrm{F}_{\mathrm{CSF}}\right)$, faktor penyesuaian kapasitas untuk ukuran kota ( $\left.\mathrm{F}_{\mathrm{CCS}}\right)$ berdasarkan Manual Kapasitas Jalan Indonesia (MKJI, 1997) untuk perhitungan ruas jalan perkotaan. Dengan melihat dan membandingkan kondis-kondisi jalan disekitar kawasan Kota Baru Lampung maka diharapkan jalan yang ada pada kawasan Kota Baru Lampung dapat memenuhi kapasitas untuk lebar jalur lalu lintas yang dapat menyesuaikan dalam mendesain pada ruang milik jalan (rumija) pada kawasan Kota Baru Lampung.

\section{Hasil Evaluasi Desain Jalan Kota baru.}

Yang membedakan jenis pembangunan jalan adalah lokasi ruas jalan yang akan dibangun (FHWA, 2012). Seperti yang disebutkan oleh Mulmi (2009) bahwa pembangunan jalan yang dilakukan di ruas jalan antar kota dengan medan pergunungan akan membutuhkan analisis keseimbangan galian-timbunan, penggunaan material lokal, dan partisipasi masyarakat lokal. Sedangkan pembangunan jalan di area perkotaan akan lebih mengarah pada perancangan peningkatan pergerakan (mobilitas dan aksesibilitas), ekologi (pengendalian air, perlindungan udara), dan permukiman (kenyamanan dan lansekap jalan), seperti 
pengalaman yang disampaikan oleh Greenberg (2008). Praktek- praktek pelaksanaan pembangunan jalan berkelanjutan yang disebutkan oleh Greenberg (2008) dan Mulmi (2009) adalah adalah sebagian kecil bagian pembangunan berkelanjutan. Praktek pembangunan berkelanjutan seyogyanya dilakukan di setiap tahap perencanaan, perancangan, pelaksanaan, dan operasi ruas jalan, seperti yang ditunjukkan oleh Greenroads, INVESTVicRoads, INVEST-FHWA, dan I-LAST.

Prinsip yang harus ada sebagai prinsip jalan berkelanjutan adalah efisiensi, mobilitas, aksesibilitas, selamat dan nyaman, partisipasi masyarakat, pembatasan emisi, sumber daya alam, habitat, dan ekosistem. Prinsip-prinsip tersebut dikelompokkan pada aspek-aspek ekonomi, sosial, dan lingkungan. Tabel 2 menunjukkan prinsip-prinsip pembangunan jalan berkelanjutan.

1. Type Jalan Utama dalam Kajian Poros Itera Provinsi Lampung.

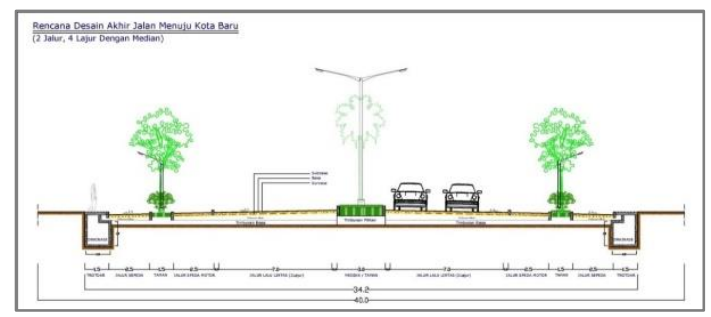

Gambar. 6 type jalan utama

2. Type Jalan Kolektor Primer dalam Master Plan Kota Baru Provinsi Lampung.

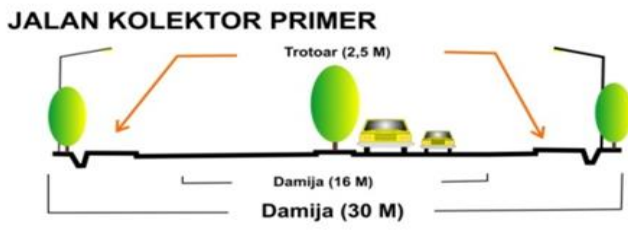

Gambar .7 type jalan kolektor primer
3. Type Jalan Jalan Kolektor Sekuder dalam Master Plan Kota Baru Provinsi Lampung.

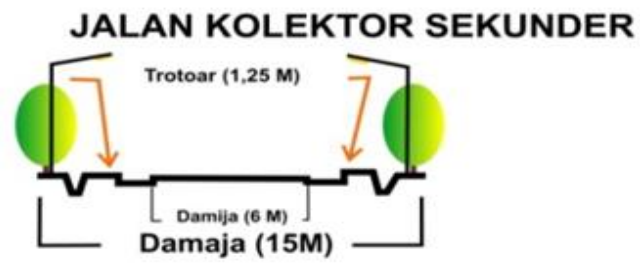

Gambar 8 type jalan kolektor sekunder

Tabel 1 Perhitungan Ruang Terbuka Hijau dan Ruang Terbuka Non Hijau pada jalan di kawasan Kota Baru Provinsi Lampung.

\begin{tabular}{|c|c|c|c|c|}
\hline No & Type Jalan & $\begin{array}{c}\text { Ruang } \\
\text { Terbuka } \\
\text { Hijau }\end{array}$ & $\begin{array}{c}\text { Ruang } \\
\text { Terbuka } \\
\text { Non Hijau }\end{array}$ & $\begin{array}{c}\text { Prosentase RTH } \\
(\%)\end{array}$ \\
\hline 1 & $\begin{array}{l}\text { Jalan Utama } \\
\text { a. Perkerasan jalan } \\
\text { b. Perkersaan jalan } \\
\text { Pendistrian } \\
\text { c. Ruang Hijau Pembatas } \\
\text { Jalan } \\
\text { d. Taman pendistrian }\end{array}$ & $\begin{array}{l}2 \text { meter } \\
3 \text { meter }\end{array}$ & $\begin{array}{l}14 \text { meter } \\
10 \text { meter }\end{array}$ & $\begin{array}{l}\text { Jadi Prosentase RTH } \\
\text { jalan Utama di kota } \\
\text { baru adalah: } \\
=\text { RTH } / \text { RTnonH } \\
=(6 / 30) \times 100 \% \\
=20 \%\end{array}$ \\
\hline 2 & $\begin{array}{l}\text { Jalan Kolektor Primer } \\
\text { a. Perkerasan jalan } \\
\text { b. Perkersaan jalan } \\
\text { Pendistrian } \\
\text { c. Ruang Hijau Pembatas } \\
\text { Jalan } \\
\text { d. Taman pendistrian }\end{array}$ & $\begin{array}{l}2 \text { meter } \\
2 \text { meter }\end{array}$ & $\begin{array}{l}14 \text { meter } \\
5 \text { meter }\end{array}$ & $\begin{array}{l}\text { Jadi Prosentase RTH } \\
\text { jalan Kolektor } \\
\text { Primer di kota baru } \\
\text { adalah: } \\
=\text { RTH } / \text { RTnonH } \\
=(4 / 23) \times 100 \% \\
=17,39 \%\end{array}$ \\
\hline 3 & $\begin{array}{l}\text { Jalan Kolektor Sekuder } \\
\text { a. Perkerasan jalan } \\
\text { b. Perkersaan jalan } \\
\text { Pendistrian } \\
\text { c. Ruang Hijau Pembatas } \\
\text { Jalan } \\
\text { d. Taman pendistrian }\end{array}$ & $\begin{array}{l}0 \text { meter } \\
2 \text { meter }\end{array}$ & $\begin{array}{l}9 \text { meter } \\
2.5 \text { meter }\end{array}$ & $\begin{array}{l}\text { Jadi Prosentase RTH } \\
\text { jalan Kolektor } \\
\text { Sekuder di kota baru } \\
\text { adalah : } \\
=\text { RTH } / \text { RTnonH } \\
=(2 / 11,5) \times 100 \% \\
=17,39 \%\end{array}$ \\
\hline
\end{tabular}

Tabel.2 prinsip-prinsip pembangunan jalan berkelanjutan

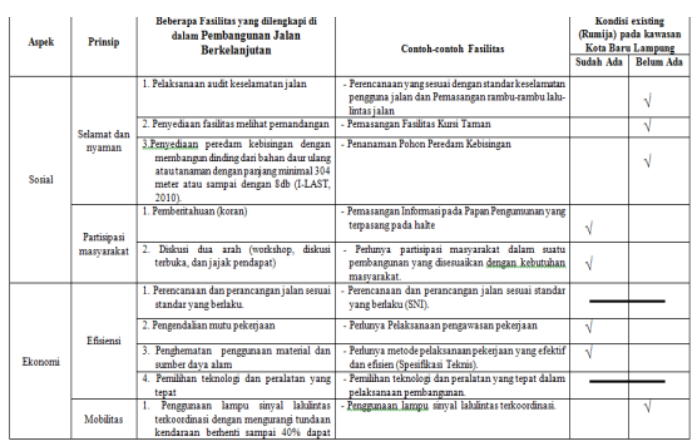




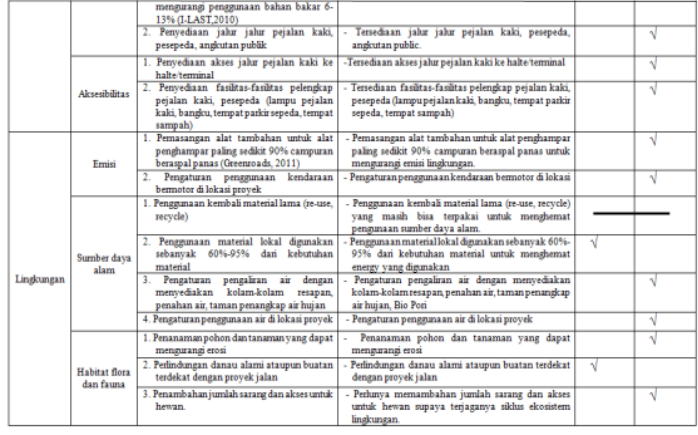

Prinsip efisiensi dengan perencanaan yang baik dapat memperpanjang umur layan jalan tersebut dan meminimumkan kegiatan pemeliharaan maupun rehabilitasi jalan. Hal ini dapat diwujudkan bila penyedia jasa perencana jalan telah memahami dan melaksanakan sistem manajemen mutu dan sistem manajemen lingkungan serta terdapat koordinasi yang baik antara perencana dan pelaksana di lapangan. Prinsip mobilitas dan aksesibilitas yang tinggi digambarkan dengan adanya kelancaran perjalanan dan resiko terjadi konflik lalulintas, sehingga terjadi penghematan biaya perjalanan. Berdasarkan hasil checklist dari table Prinsip Pembangunan Jalan Berkelanjutan pada Kawasan Kota Baru Lampung di atas maka dapat ditarik kesimpulan bahwa dari aspek sosial, aspek ekonomi dan aspek lingkungan masih perlu adanya perbaikan supaya memenuhi kaidah-kaidah dari pada jalan yang jalan berkelanjutan yang berwawasan lingkungan.

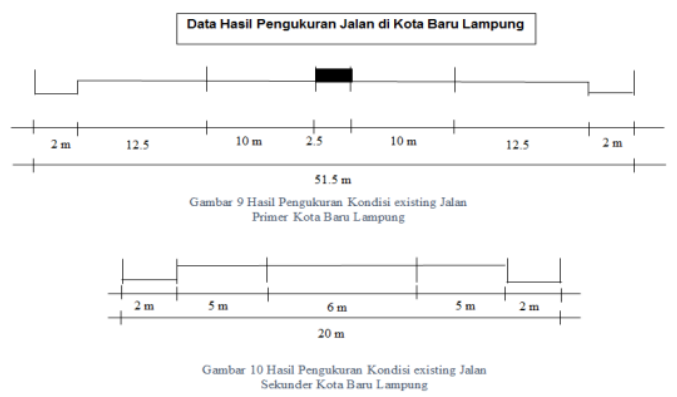

Gambar. 9 Kondisi eksisting Jalan Primer dan Jalan Sekunder Kota Baru Lampung

\section{KESIMPULAN DAN SARAN}

\section{a. Kesimpulan}

Berdasarkan hasil analisis ini sangatlah diperlukan beberapa hal yang merupakan interpretasi terhadap informasi (data) hasil analisis:

1. Ruang terbuka hijau (RTH) sangatlah diperlukan dalam suatu pembangunan suatu kawasan baru agar pembangunan berkelajutan dapat terlaksana dan dampakdampak negative dari pembangunan suatu kawasan dapat diminimalisir.

2. Kondisi ruang milik jalan (rumija) didalam perencanaan Masterplan dan kondisi eksisting dari Kota Baru Lampung perlunya ditinjau kembali kedalam prinsipprinsip pembangunan jalan berkelanjutan.

3. Perlu dilakukan koordinasi dengan pihak pemerintah daerah, terutama yang berhubungan dengan rencana pembangunan yang dilaksanakan di Kota Baru agar dapat memakai konsep kawasan hijau.

\section{b. Saran}

1. Konsep desain jalan yang berwawasan lingkungan selayaknya di implementasikan dan dikembangkan dalam setiap pengembangan suatu wilayah.

2. Kriteria ruang milik jalan (rumija) ramah lingkungan perlu di sosialisasikan kepada para perencana, pelaksana kontruksi, pemerintah daerah dan masyarakat umum agar setiap perancangan ruang milik jalan (rumija) sebanyak mungkin memenuhi kriteria ramah lingkungan, sehingga terjadi peningkatan kualitas lingkungan dan mengurangi dampak 
buruk dari kerusakan lingkungan.

3. Saran desain di bawah ini telah menyesuaikan dengan peraturanperaturan yang berlaku serta juga telah mengindahkan dari prinsipprinsip pembangunan jalan berkelanjutan, Desain ini diharapkan dapat terimplementasi kedalam tahap pembangunan jalan yang berwawasan lingkungan terutama pada kawasan Kota Baru Lampung dimana sebagai tempat lokasi analisis ini dilakukan.

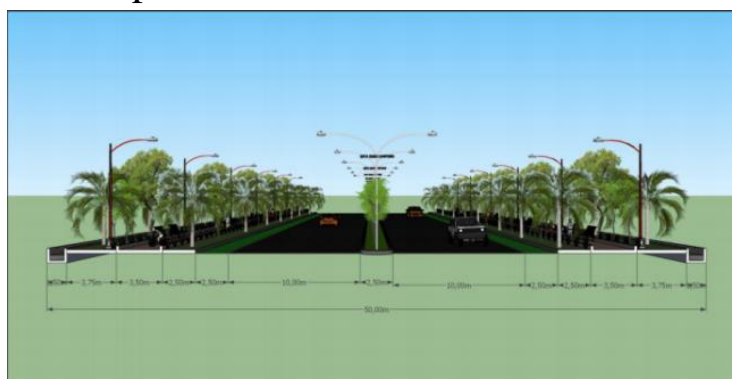

Gambar 10 Tampak Depan Desain Jalan Primer Kota Baru Lampung.

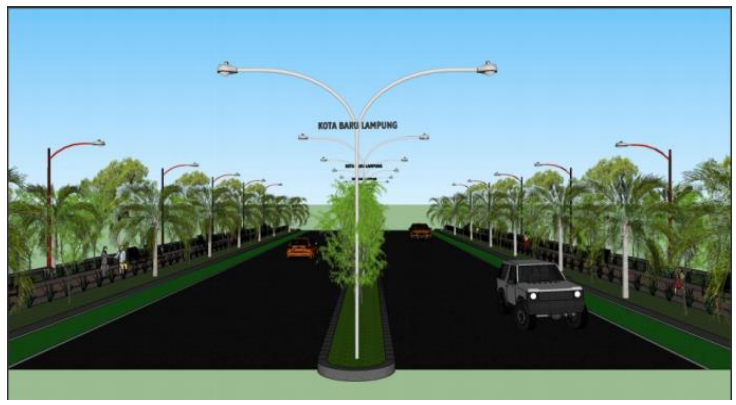

Gambar 11 Tampak 3 Dimensi Desain Jalan Primer Kota Baru Lampung

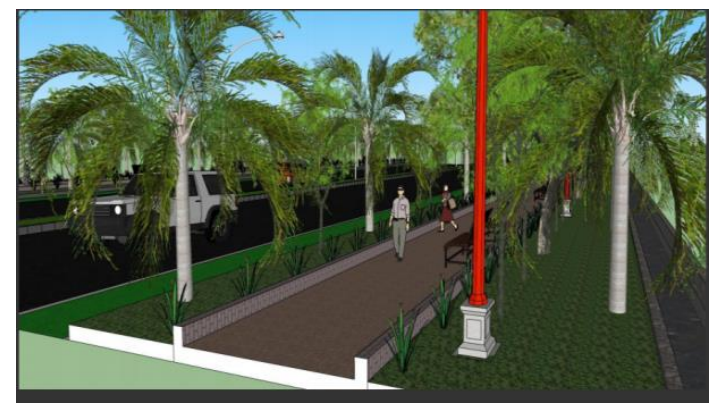

Gambar 12 Tampak 3 Dimensi Desain Jalan Primer Kota Baru Lampung

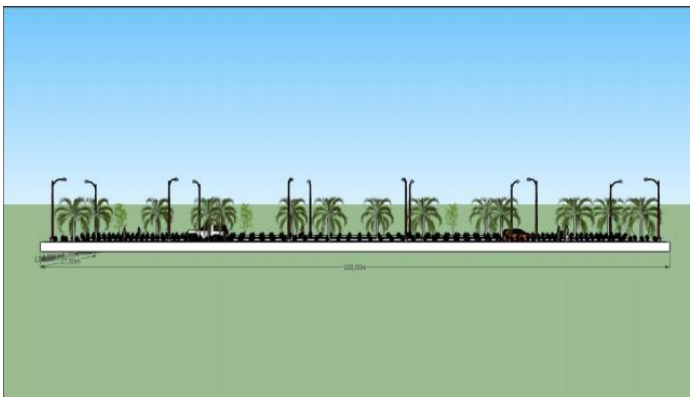

Gambar 13 Tampak Samping Desain Jalan Sekunder Kota Baru Lampung.

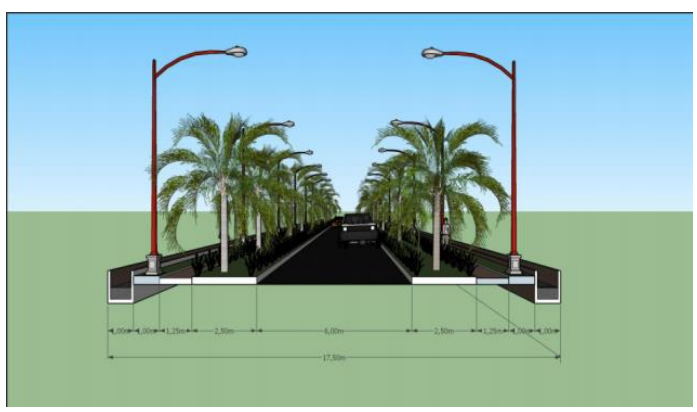

Gambar 14 Tampak 3 Dimensi Desain Jalan Sekunder Kota Baru Lampung

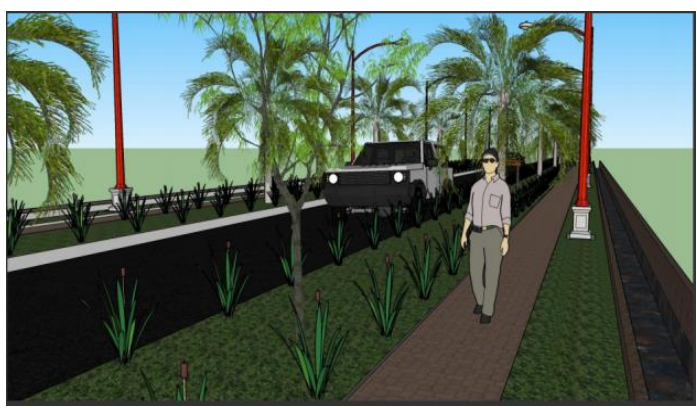

Gambar 15 Tampak 3 Dimensi Desain Jalan Sekuder Kota Baru Lampung

\section{DAFTAR PUSTAKA}

Surjana, T.S \& Ardiansyah. 2013. Perancangan Arsitektur Ramah Lingkungan:Pencapaian Rating Greenship GBCI . Jurnal Arsitektur Universitas Bandar Lampung No.3 Vol.2. 
Balitbangda, 2015. Kajian Penataan Pengembangan Poros ITERA, IAIN, Kotabaru Terkait Dampak Pembangunan

Tol Tras Sumatera.

Balitbangda, 2018. Bunga Rampai Pemikiraan Tenaga Ahli Pemerintah Provinsi Lampung.

Karyono, T.H 2010. Green Architecture Pengantar Pemahaman Arsitektur Hijau di Indonesia, Jakarta PT. Rajagrafindo Persada.

Dinas Cipta Karya dan Sumber Daya Air Provinsi Lampung, 2000 Master Plan Kota Baru Lampung.

Departemen Pekerjaan Umum, Peraturan Meteri Pekerjaan Umum, 2008 Pedoman Penyediaan dan Pemanfaatan RTH di Kawasan Perkotaan.

Karuniaastuti, N 2013. Bangunan Ramah Lingkungan . Jurnal Pusdiklat Migas. ESDM No.1 Vol.05.

Lawalata, M.G 2013. Prinsip-Prinsip Pembangunan Jalan Berkelanjutan. Jurnal Transportasi No.2 Vol.13.

Karuniastuti, N 2015. Bangunan Ramah Lingkungan. Jurnal Forum Teknologi No.5 Vol.1.

Direktorat Jenderal Bina Marga, Departemen Pekerjaan Umum. 1997. Manual Kapasitas Jalan Indonesia (MKJI).

Mulmi, A, D. 2009. Green Road Approachin Rural Road Construction for the Sustainable Development of Nepal. Journal of Sustainable Development, No. 3 Vol. 2. 


\section{Halaman Kosong}

